\title{
OTOLOGY
}

\section{The safety of povidone-iodine solution in tympanoplasty: a randomised, triple-blind, placebo-controlled study}

\author{
Valutazione della sicurezza nell'utilizzo della soluzione con iodopovidone \\ nella timpanoplastica: studio placebo-controllo, in triplo cieco randomizzato
}

\author{
Behrouz Barati, Mahboobe Asadi, Matin Ghazizadeh, Ghazal Norouzi \\ Otolaryngology Department, Shahid Beheshti University of Medical Sciences, Tehran, Iran
}

\section{SUMMARY}

Objective. Nowadays, povidone-iodine is commonly used as a disinfectant in head and neck procedures. The present study investigated the effect of povidone-iodine, which is used as a disinfectant solution in tympanoplasty, on patients' hearing.

Methods. A povidone-iodine solution was used as disinfection in chronic otitis media patients undergoing tympanoplasty. In the intervention group, $5 \%$ povidone-iodine, was applied to the external auditory canal and remained there for 10 minutes. In the control group, povidoneiodine was used but not allowed to enter the external auditory canal by inserting cotton wool into the canal. To evaluate the adverse effect of povidone-iodine on hearing, the bone conduction level was compared between groups at baseline and one month after exposure.

Results. Bone conduction levels at frequencies $500 \mathrm{~Hz}, 1 \mathrm{kHz}, 2 \mathrm{kHz}, 3 \mathrm{kHz}, 4 \mathrm{kHz}$ and 8 $\mathrm{kHz}$ and mean of bone conduction level in $500 \mathrm{~Hz}, 1 \mathrm{kHz}$ and $2 \mathrm{kHz}$ were measured and compared respectively between intervention and control group. No significant difference was seen between bone conduction levels of above frequencies and mean frequencies before and one month after surgery. $(\mathrm{P}$-value $=0.321,0.432,0.219,0.489,0.61,0.112,0.324$ respectively $)$

Conclusions. According to the present study, currently available $5 \%$ povidone-iodine did not affect hearing and therefore, can be comfortably used for preparation and disinfection in otologic surgeries.

KEY WORDS: povidone- iodine, tympanoplasty, otitis media

\section{RIASSUNTO}

Obiettivo. Al giorno d'oggi, lo iodio-povidone è comunemente usato come disinfettante nelle procedure della testa e del collo. Il presente studio ha esaminato l'effetto del povidone-iodio, che viene utilizzato come soluzione disinfettante nella timpanoplastica, sull'udito dei pazienti. Metodi. La soluzione di iodio-povidone è stata utilizzata come disinfettante in pazienti con otite media cronica sottoposti a timpanoplastica. Nel gruppo di intervento, lo iodio povidone al 5\% è stato applicato al canale uditivo esterno e vi è rimasto per dieci minuti. Nel gruppo di controllo, è stato usato iodio-povidone ma non gli è stato permesso di entrare nel canale uditivo esterno inserendo un batuffolo di cotone nel canale. Per valutare l'effetto avverso dello iodio-povidone sull'udito, è stato valutato il livello di conduzione ossea nei gruppi di trattamento, prima dell'intervento e un mese dopo l'esposizione.

Risultati. Vengono misurati e confrontati i livelli di conduzione ossea a frequenze di $500 \mathrm{~Hz}$ (hertz), $1 \mathrm{kHz}$ (kilohertz), $2 \mathrm{kHz}, 3 \mathrm{kHz}, 4 \mathrm{kHz}$ e $8 \mathrm{kHz}$ e il livello medio di conduzione ossea a $500 \mathrm{~Hz}, 1 \mathrm{kHz}$ e $2 \mathrm{kHz}$ rispettivamente tra gruppo di intervento e gruppo di controllo. Non è stata osservata alcuna differenza significativa tra i livelli di conduzione ossea delle singole frequenze e delle frequenze medie prima e un mese dopo l'intervento chirurgico. (Valore $P=0,321,0,432,0,219,0,489,0,61,0,112,0,324$ rispettivamente).

Conclusioni. Secondo il presente studio, iodio-povidone al $5 \%$ attualmente disponibile non ha diminuito l'udito e quindi può essere tranquillamente utilizzato per la preparazione e la disinfezione nella chirurgia otologica.

PAROLE CHIAVE: povidone, iodio, timpanoplastica, otite media
Received: January 9, 2021

Accepted: February 27, 2021

Correspondence

Mahboobe Asadi

Taleghani Educational Hospital,Tabnak St. Velenjak

Region, Chamran High Way, Tehran, Iran

Tel. +98 21230311 Fax +98 2122432570

E-mail: mahboobeh_farvardin@yahoo.com

Funding

None.

Conflict of interest

The Authors declare no conflict of interest.

How to cite this article: Barati B, Asadi M, Ghazizadeh M, et al. The safety of povidoneiodine solution in tympanoplasty: a randomised, triple-blind, placebo-controlled study. Acta Otorhinolaryngol Ital 2021;41:377-382. https:// doi.org/10.14639/0392-100X-N1369

(C) Società Italiana di Otorinolaringoiatria e Chirurgia Cervico-Facciale

\section{(c) (1) $(9)$}

This is an open access article distributed in accordance with the CC-BY-NC-ND (Creative Commons Attribution-NonCommercial-NoDerivatives 4.0 International) license. The article can be used by giving appropriate credit and mentioning the license, but only for non-commercial purposes and only in the original version. For further information: https:// creativecommons.org/licenses/by-nc-nd/4.0/deed.en 


\section{Introduction}

Pre-surgical antiseptics are known materials that reduce the number of wound infections when used adequately and safely ${ }^{1-3}$. Standard antiseptic preparations may cause toxicity to the eyes and ears in head and neck surgeries ${ }^{4}$. Currently, there is much uncertainty regarding the safety of surgical antiseptic preparations in the ear. This concern has been a longstanding area of research. In the early 1960s, Bicknell et al. described varying degrees of morbidity following tympanoplasty with the pre-surgical preparation of the ear with chlorhexidine ${ }^{5}$.

In addition, iodine has been proven to be antiseptic for many years and has been used for a long time. At the end of the $19^{\text {th }}$ century, the bactericidal effect of iodine was established ${ }^{4,6,7}$. Although it is effective against a wide range of microbes, no resistance has been reported up to now. Polyvinyl pyrrolidone (povidone)-bound iodine is an effective formulation of iodine which was proven by in vivo testing to be faster acting and more effective against a large number of pathogens than topical antibiotics. This formulation's broad-spectrum antimicrobial activity and efficacy are well documented, especially against resistant microorganisms, such as methicillin-resistant Staphylococcus aureus ${ }^{8,9}$.

Moreover, studying the effect of povidone-iodine on the treatment of chronic otitis media showed that topical povidone-iodine is as effective as topical ciprofloxacin ${ }^{4}$. However, it was proven to be ototoxic in many animal studies and a small number of human case reports ${ }^{2,7}$, and to our best of knowledge there is no documented trial reporting the human ototoxicity of povidone-iodine. Given its valuable antiseptic properties, in the present study, we assessed the ototoxic effect of povidone-iodine during surgery for chronic otitis media.

\section{Materials and methods}

This trial was conducted according to the CONSORT statement ${ }^{10}$.

\section{Design overview}

This study was a randomised, triple-blind, controlled trial, approved by the local ethics committee of Shahid Beheshti University of medical sciences (IR.SBMU.MSP. REC.1396.581), the Iran randomised clinical trial (IRCT) database (IRCT20200926048841N1). All participants gave written informed consent.

\section{Setting and participants}

The study was conducted at the Department of Otolaryngology and Head and Neck Surgery, Taleghani Hospital, Tehran, Iran. In this trial, patients were eligible for inclu- sion if they had chronic otitis media with tympanic membrane perforation and were a surgical candidate. Exclusion criteria were: 1) cholesteatoma, 2) previous middle ear surgery, 3) local skin disturbance, 4) uncontrolled hyperglycaemia, 5) concurrent ossicular chain manipulation or mastoidectomy during tympanoplasty.

All patients underwent temporal high-resolution computed tomography before surgery to rule-out any underlying middle or inner ear malformations caused hearing loss.

\section{Randomisation and interventions}

Patients were randomly assigned to two groups with the block randomisation method. In the intervention group, $5 \mathrm{cc}$ of povidone-iodine (5\% povidone-iodine solution, Medipharma, Iran) was applied in the external auditory canal just before tympanoplasty and allowed to stay in the canal for 10 minutes. In the control group, $5 \%$ povidone-iodine solution was administered before surgery and was not allowed to enter the external auditory canal by inserting cotton wool into the canal. After prepping, the ear was irrigated with saline by the surgeon's assistant and the main surgeon started tympanoplasty, so that the main surgeon was not aware of the patient's group. Patients, researchers, and study statisticians were also masked to treatment allocation. All surgeries were done by the senior author of this article in the standard academic settings. Other probable confounding factors such as pre-operative ototoxic drug use, excessive noise exposure, infections, etc. were adjusted.

\section{Outcomes and follow-up}

We assessed hearing status at baseline and one month after surgery with bone conduction level. Standard bone conduction levels (frequencies $500 \mathrm{~Hz}, 1 \mathrm{kHz}, 2 \mathrm{kHz}, 3 \mathrm{kHz}, 4$ $\mathrm{kHz}$, and $8 \mathrm{kHz}$ ) and mean of bone conduction levels (frequencies $500 \mathrm{~Hz}, 1 \mathrm{kHz}$, and $2 \mathrm{kHz}$ ) were measured and compared between groups. Patients were followed on the seventh day for any surgical complications.

\section{Statistical analysis}

All data were analysed using IBM SPSS Statistics for Windows, Version 20.0. Chi-square test and exact Fischer test was used to compare the results. A two-sided $\mathrm{P}$ value of $\leq 0.05$ was set as a statistically significant threshold.

\section{Results}

Patients were recruited from July 2018 to December 2019. The CONSORT flow diagram (Fig. 1) shows the allocation, follow-up and analysis process. Eighty patients were assessed for eligibility, 14 were excluded due to cholesteatoma $(n=3)$, previous middle ear surgery $(n=5)$, con- 


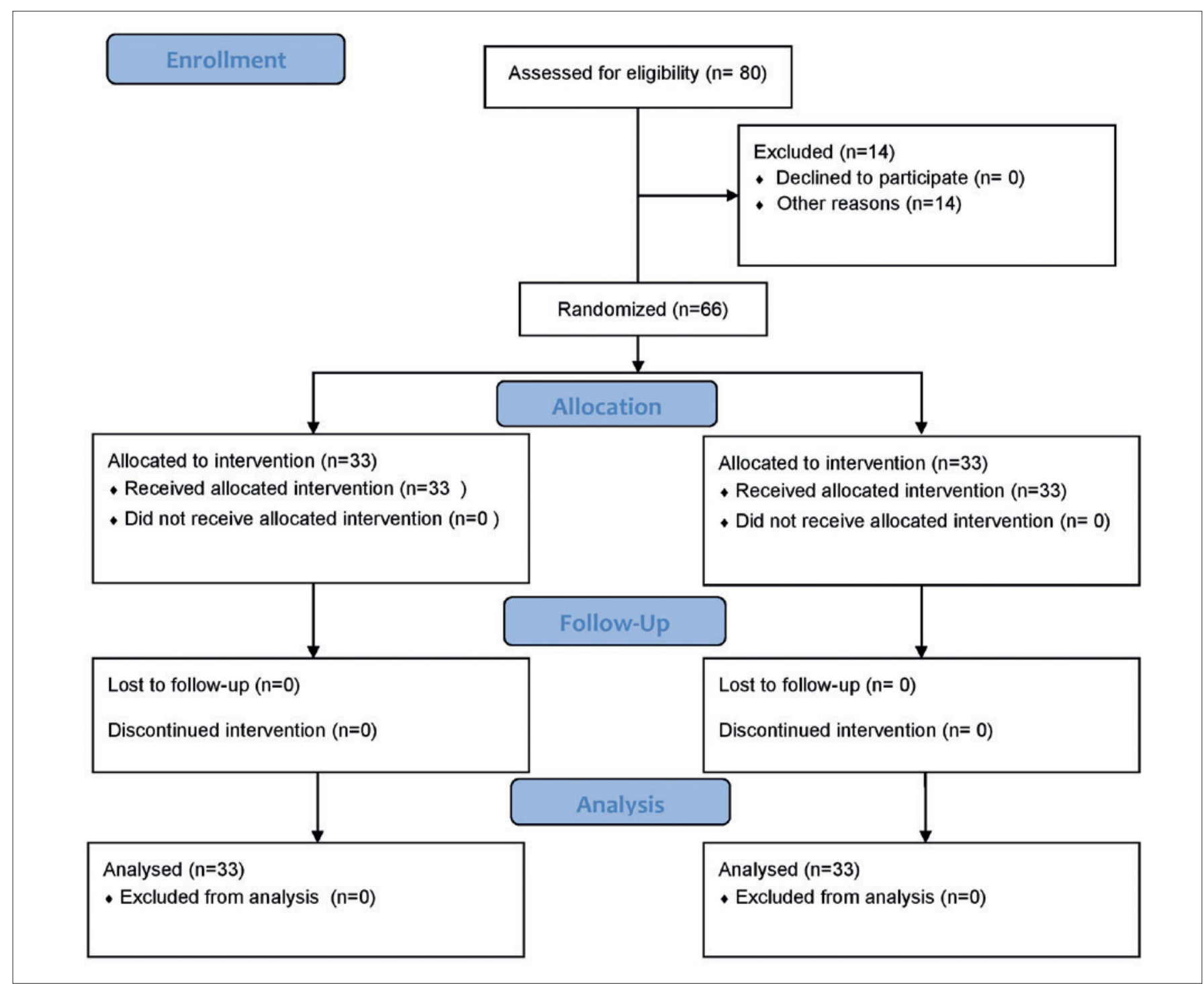

Figure 1. Consort diagram showed the participants allocation, intervention and follow-up.

current ossicular chain manipulation or mastoidectomy $(n=6)$. Thus, the remaining 66 patients were randomised to the intervention $(n=33)$ or control group $(n=33)$. The primary assessment demonstrated that the baseline characteristics were similar between groups. None of the patients reported a history of ototoxic drug consumption during the preoperative period based on the history and medical records assessment.

In this trial, 66 patients ( 32 females and 34 males) with a mean age of $42.12 \pm 11.33$ were enrolled. The youngest patient was 20 years old and the oldest one was 65 years. There was no significant age difference between the two groups $(\mathrm{P}$ value $=0.455)$. All patients were randomised into two groups of 33: intervention group (18 males and
15 females), control group (16 males and 17 females), all undergoing tympanoplasty.

Evaluating the bone conduction levels in a wide range frequency $(500 \mathrm{~Hz}, 1 \mathrm{kHz}, 2 \mathrm{kHz}, 3 \mathrm{kHz}, 4 \mathrm{kHz}$ and $8 \mathrm{kHz})$ with attaining the mean value of bone conduction level ( $500 \mathrm{~Hz}, 1 \mathrm{kHz}$ and $2 \mathrm{kHz}$ ) was done for each patient. No significant difference was seen between frequency-specific bone conduction levels and mean bone conduction levels between the intervention and control groups before (P-value $=0.321,0.432,0.219,0.489,0.612,0.112,0.324$, respectively) and one month after surgery (Tab. I).

The mean of bone conduction threshold in different frequencies was also compared in the intervention and control groups before and one month after surgery. No significant 
Table I. Mean of bone conduction threshold in intervention and control group (one month after surgery).

\begin{tabular}{lccc} 
Bone threshold conduction (frequency) & Intervention & Control & P-value \\
$500 \mathrm{~Hz}$ & 7.14 & 11.07 & 0.221 \\
$1 \mathrm{kHz}$ & 8.57 & 11.64 & 0.442 \\
$2 \mathrm{kHz}$ & 12.14 & 17.14 & 0.249 \\
$3 \mathrm{kHz}$ & 16.79 & 22.14 & 0.149 \\
$4 \mathrm{kHz}$ & 18.93 & 27.14 & 0.615 \\
$8 \mathrm{kHz}$ & 20.71 & 35.23 & 0.192 \\
Mean: $500 \mathrm{~Hz}, 1 \mathrm{kHz}, 2 \mathrm{kHz}$ & 11.68 & 12.68 & 0.754 \\
\hline
\end{tabular}

difference was seen (respective $\mathrm{P}$ values were presented in Table II and Table III).

Postoperative otorrhoea was seen in 2 patients in the control group and ciprofloxacin drop was given for one week. Both patients showed clinical response on the seventh day and the treatment was stopped, and patients were advised to keep the ear dry.

\section{Discussion}

Chronic otitis media (COM) refers to chronic inflammation of the middle ear persistent for at least 3 months. Since $\mathrm{COM}$ is a common cause of reference to otolaryngology clinics, its treatment is one of the major health problems among otolaryngologists ${ }^{1,2}$. With this in mind, considering hearing loss and its serious complications proper treatment is necessary. The definitive treatment for COM is surgery with a probable need for reconstruction of the middle ear. Ultimately when there is no possibility of surgery due to bad physical conditions (age, underlying diseases, etc.), there is a need for drugs with low and acceptable ototoxicity that can be used in the long term. Although there is concern regarding the safety of antiseptic preparations in the case of surgical candidate COM, different materials have used as pre-surgical prepping such as povidone-iodine, chlorhexidine gluconate, ethanol and hydrogen peroxide. When reviewing the literature, we found a common concern about the ototoxic effect of this antiseptic solution.

Historically, the primary concern mentioned by Bicknell in the early 1960s who described pre-surgical preparation of the ear with chlorhexidine as a disturber factor in tympanoplasty that caused ototoxic effects ranging from highfrequency hearing loss to "dead ears". Comparing variant antiseptic agents demonstrate that iodine based solutions have the least harm effect in the ear, while chlorhexidine and high concentrations of alcohol-based solutions show the most harm ${ }^{11}$. Because of the widespread use of povi-

Table II. Mean bone conduction threshold in intervention group (before and one month after surgery).

\begin{tabular}{lccc} 
Bone conduction threshold (frequency) & Pre-operation & Post-operation & P-value \\
$500 \mathrm{~Hz}$ & 9.29 & 7.14 & 0.142 \\
$1 \mathrm{KHz}$ & 10.36 & 8.57 & 0.441 \\
$2 \mathrm{kHz}$ & 12.5 & 12.14 & 0.554 \\
$3 \mathrm{kHz}$ & 15.36 & 16.79 & 0.213 \\
$4 \mathrm{kHz}$ & 18.57 & 18.93 & 0.128 \\
$8 \mathrm{kHz}$ & 21.79 & 20.71 & 0.118 \\
\hline
\end{tabular}

Table III. Mean bone conduction threshold in control group (before and one month after surgery).

\begin{tabular}{lccc} 
Bone conduction threshold (frequency) & Pre-operation & Post-operation & P-value \\
$500 \mathrm{~Hz}$ & 11.43 & 11.07 & 0.21 \\
$1 \mathrm{kHz}$ & 13.93 & 14.64 & 0.232 \\
$2 \mathrm{kHz}$ & 17.86 & 17.14 & 0.519 \\
$3 \mathrm{kHz}$ & 22.50 & 22.14 & 0.89 \\
$4 \mathrm{kHz}$ & 27.50 & 27.14 & 0.712 \\
$8 \mathrm{kHz}$ & 35.83 & 35.23 & 0.312 \\
\hline
\end{tabular}


done-iodine during interventions, in this study we focused on its ototoxic effect.

Povidone-iodine is a suitable form of iodine that is used commonly as a pre-surgical disinfection method ${ }^{4,6,7}$. Disinfection with iodine has been demonstrated for many years and different solutions based on iodine have been used for this purpose. Not only it is effective against gram-negative, gram-positive, mycobacterium, treponema, fungi, viruses and protozoa but also its unique biological effect is characterised by the lack of resistance ${ }^{2}$.

When preparing the patient with tympanic membrane perforation, some of the povidone-iodine can potentially enter the middle ear, which theoretically may be harmful to the exposed middle and inner ear. All evidence pertaining to the ototoxic effect of povidone-iodine has come from a few animal studies and a small number of human case reports. In 1982, Aursnes demonstrated that middle ear exposure for more than 10 min with alcohol-based povidone-iodine solutions showed a histopathologic change in the vestibulocochlear system of guinea pigs ${ }^{6}$. Moreover, the ototoxicity of $10 \%$ povidone-iodine was assessed in guinea pigs of different ages, finding that the cochlea of infants or young pigs is more sensitive than that in adults. Ultimately, they proposed that the possible reason could be the increased permeability of the round window membrane in younger versus adult guinea pigs as the membrane thickens with age ${ }^{7}$. However, different materials can cross the round window membrane and cause toxic effects on the cochlea. In humans, no thickness change of round window membrane is apparent with aging, although this thickness can double under conditions of inflammation ${ }^{12}$. This can explain why $5 \%$ povidone-iodine does not have a toxic effect on cochlea in COM in the present study.

Among the literature reviewing the short- and long-term effects of iodine solution related ototoxicity, Ozkiris mentioned that $5 \%$ povidone-iodine solution led to significant short-term hearing loss on the first day that resolved by day 10 while, at $7.5 \%$ and $10 \%$, there was a decrease in hearing that persisted for at least 10 days in rats ${ }^{13}$. Yagiz detected no effects following $10 \%$ povidone-iodine exposure at 10 days and 4 weeks in guinea pigs ${ }^{14}$.

Another animal study showed that commercially available high concentration povidone-iodine solutions may cause significant ototoxic effects when applied topically through a perforated eardrum in rats. Based on this experiment, high concentration povidone-iodine solutions should not be used for preoperative surgical site cleaning for otologic surgery ${ }^{15}$. However, this result related to rats and may not be applied to humans.

Furthermore, the effect of topical povidone-iodine on the treatment of COM was studied. According to the findings, topical povidone-iodine is as effective as topical ciprofloxacin. The same result concluded comparing povidone-iodine and neomycin. Topical povidone-iodine showed effect similar to neomycin solution in the treatment of $\mathrm{COM}^{4}$. Currently, povidone-iodine solution is available in concentrations of $5 \%, 7.5 \%$ and $10 \%$ weight/volume. The concentration might affect the severity of the hearing loss. Moreover, based on the properties of the solvent, different effects of povidone-iodine (aqueous solution or alcoholic solution) may be expected. Although the alcoholic solution may show greater antimicrobial potential, its ototoxic effect seems to be higher as well ${ }^{16}$.

To our knowledge, no previous study has directly assessed the potentially toxic effects of povidone-iodine on the human ear. In this trial, we studied the toxic effects of povidone-iodine used as a disinfection solution for the presurgical preparation of patients undergoing tympanoplasty. Although povidone-iodine showed an ototoxic effect in animal studies and some toxic effects at high concentrations in case reports in humans, in our survey no short term cochlear toxicity of povidone-iodine was detected based on audiometric evaluation.

This study has some limitations. First, this is a singlecentre study with a small sample size. Thus, it may not be representative of the overall population. Second, there was a short follow-up time, and patients were observed for one month.

Although there is some evidence that iodine antiseptics have ototoxicity, the conclusive evidence for the human ototoxic effect of the povidone-iodine solution is weak. To increase the statistical accuracy and ensure the use of povidone-iodine, a larger study with prolonged follow-up should be considered.

\section{Conclusions}

Based on our findings, no povidone-iodine related hearing impairment was detected during short term follow-up. Thus, povidone-iodine can be considered as a safe disinfectant solution for otologic surgery.

\section{Acknowledgements}

The authors would like to thank Dr. Alimohammad Fakhr Yasseri for his dedicated support and guidance.

\section{References}

1 Singh S, Blakley B. Systematic review of ototoxic pre-surgical antiseptic preparations - what is the evidence? J Otolaryngol Head Neck Surg 2018;47:18. https://doi.org/10.1186/s40463-018-0265-z 
2 Jaya C, Job A, Mathai E, et al. Evaluation of topical povidone-iodine in chronic suppurative otitis media. Arch Otolaryngol Head Neck Surg 2003;129:1098-1100. https://doi.org/10.1001/archotol.129.10.1098

3 Dobson PF, Reed MR. Prevention of infection in primary THA and TKA. EFORT Open Rev 2020;5:604-613. https://doi. org/10.1302/2058-5241.5.200004

4 Al-Abbasi AM. Efficacy of povidone iodine in treatment of active chronic suppurative otitis media. JIMA 2006;38:118-121. https://doi. org/10.5915/38-3-5986

5 Arslan IB, Genc S, Kayhan BC, et al. Bacterial change in external auditory canal upon antisepsis with povidone-iodine during tympanoplasty. Eur Arch Otorhinolaryngol 2015;272:551-555. https://doi. org/10.1007/s00405-013-2864-7

6 Aursnes J. Ototoxic effect of iodine disinfectants. Acta Otolaryngol 1982;93:219-226. https://doi.org/10.3109/00016488209130875

7 IchibangaseT,YamanoT,MiyagiM,etal.Ototoxicity of povidone-iodine applied to the middle ear cavity of guinea pigs. Int J Pediatr Otorhinolaryngol 2011;75:107881. https://doi.org/10.1016/j. ijporl.2011.05.013

8 Morizono T, Sikora MA. The ototoxicity of topically applied povidone-iodine preparations. Arch Otolaryngol 1982;108:210-213. https://doi.org/10.1001/archotol.1982.00790520010004

9 Morizono T, Sikora MA. Compound action potential inputoutput decruitment. Effect of topically applied antiseptics.
Arch Otolaryngol 1983;109:677-681. https://doi.org/10.1001/ archotol.1983.00800240043008

10 Moher D, Hopewell S, Schulz KF, et al. CONSORT 2010 explanation and elaboration: updated guidelines for reporting parallel group randomised trials. BMJ 2010;340:869. https://doi.org/10.1136/bmj.c869

11 Bicknell P. Sensorineural deafness following myringoplasty operations. J Laryngol Otol 1971;85:957-962. https://doi.org/10.1017/ S0022215100074272

12 Sahni RS, Paparella MM, Schachern PA, et al. Thickness of the human round window membrane in different forms of otitis media. Arch Otolaryngol Head Neck Surg 1987;113:630-634. https://doi. org/10.1001/archotol.1987.01860060056015

13 Ozkiris M, Kapusuz Z, Saydam L. Ototoxicity of different concentrations povidone-iodine solution applied to the middle ear cavity of rats. Indian J Otolaryngol Head Neck Surg 2013;65:168-172. https://doi. org/10.1007/s12070-012-0615-5

14 Yagiz R, Tas A, Uzun C, et al. Effect of topically applied povidone-iodine on transient evoked otoacoustic emissions in guinea pigs. J Laryngol Otol 2003;117:700-703. https://doi. org/10.1258/002221503322334512

15 Rauch S. Membrane problems of the inner ear and their significance. J Laryngol Otol 1966;80:1144-1155. https://doi.org/10.1017/ S0022215100066500

16 Patorn P. Ototoxicity of povidone-iodine - A case report. J Otol 2019;14:30-32. https://doi.org/10.1016/j.joto.2018.11.005 